\title{
POLA INTERAKSI KOMUNITAS MBOJO DENGAN MASYARAKAT \\ SASAK (STUDI PADA KOMUNITAS MBOJO DI DESA PERESAK \\ KECAMATAN NARMADA KABUPATEN LOMBOK BARAT)
}

\section{MUHAMMAD SYARIFUDIN}

Dosen Universitas Islam Negeri Mataram

Email: syarifuddinhaerudin@uinmataram.ac.id

\begin{abstract}
Abstrak
Tujuan penelitian ini adalah: 1.) Untuk mengetahui pola interaksi komunitas Mbojo dengan masyarakat Sasak di Desa Peresak Kecamatan Narmada Kabupaten Lombok Barat. 2.) Untuk mengetahui proses interaksi komunitas Mbojo dengan masyarakat Sasak di Desa Peresak Kecamatan Narmada Kabupaten Lombok Barat. Penelitian ini, menggunakan jenis deskriptif dan fenomenologi. Yaitu tindakan manusia menjadi suatu hubungan sosial bila manusia memberi arti atau makna tertentu terhadap tindakannya itu, dan manusia lain memahami pula tindakannya itu sebagai sesuatu yang penuh arti. Sedangkan jenis deskriptif pada hakekatnya adalah mencari teori, bukan menguji teori. Metode ini menitik beratkan pada observasi dan suasana alamiah. Hasil penelitian ini menunjukan bahwa: 1). Pola Interaksi komunitas Mbojo dengan masyarakat Sasak di Desa Peresak Kecamatan Narmada Kabupaten Lombok Barat adalah memegang prinsip hidup dari leluhurnya yaitu memberi contoh yang terbaik dengan bilhal dari yang lebih tua para tokoh komunitas Mbojo yang sekaligus menjadi panutan dan perilaku hidup komunitas Mbojo yang juga di dalamnya mengajarkan bahwa masyarakat harus lebih bersahaja dari pada pemimpinnya dalam berinteraksi. 2). Proses interaksi komunitas Mbojo dengan masyarakat Sasak di Desa Peresak Kecamatan Narmada Kabupaten Lombok Barat merupakan segala bentuk aktifitas atau kegiatan yang dilakukan setiap hari yang memegang teguh ajaran leluhur yang disebut "maja la bo dahu" yang berarti malu dengan takut dan tercermin dalam tiga kategori, yaitu segi pekerjaan, segi kekeluargaan dan segi adat-istiadat yang merupakan keseluruhan pengetahuan dan pengalaman tentang segala aspek dan lika-liku yang berkaitan dengan kehidupan yang dipesankan secara lisan oleh nenek moyang kepada seluruh masyarakat adat Mbojo.
\end{abstract}

Kata kunci: Pola, Interaksi, Komunitas, Masyarakat, Mbojo dan Sasak.

\section{Pendahuluan}

Sebagai makhluk sosial, manusia senantiasa berhubungan dengan manusia lainnya, manusia selalu ingin mengetahui lingkungan sekitarnya, bahkan ingin mengetahui apa yang terjadi dalam dirinya, karena setiap orang yang hidup dalam masyarakat sejak ia baru lahir hingga ia menutup mata, secara kodrati senantiasa terlibat dalam berinteraksi, terjadinya interaksi adalah sebagai konsekuensi hubungan sosial masyarakat, paling sedikit dua orang yang saling berhubungan satu sama lainnya yang menimbulkan sebuah interaksi sosial (Social 
Interaction), terjadinya interaksi sosial disebabkan interkomunikasi. ${ }^{1}$ Interaksi sangat penting peranannya bagi kehidupan sosial, budaya, politik dan pendidikan, karena interaksi merupakan proses dinamik transaksional yang mempengaruhi perilaku, yang mana sumber dan penerimaannya sengaja menyandi (simbol) perilaku mereka untuk menghasilkan pesan yang mereka salurkan melalui suatu saluran guna merangsang atau memperoleh sikap atau perilaku tertentu sebagai konsekuensi dari hubungan sosial. ${ }^{2}$

Kegiatan manusia akan selalu dibarengi dengan proses interaksi, baik interaksi dengan alam lingkungan, interaksi dengan sesama, maupun dengan Tuhannya, baik dengan disengaja maupun tidak disengaja. Menurut H. Booner sebagaimana yang dikutip Abu Ahmadi berpendapat bahwa interaksi ${ }^{3}$ adalah memberikan rumusan interaksi yaitu hubungan antara dua individu atau lebih, dimana kelakuan individu yang satu mempengaruhi, mengubah, atau memperbaiki kelakuan individu lain atau begitu juga sebaliknya." Manusia sebagai makhluk sosial, didalam kehidupannya membutuhkan hubungan dengan manusia lainnya. Hubungan itu terjadi karena setiap manusia memiliki kebutuhan yang berbeda-beda dan karena saling membutuhkan, membuat manusia cenderung untuk berhubungan melahirkan komunikasi dua arah melalui bahasa dan mengandung tindakan dan perbuatan. Karena ada aksi dan reaksi, interaksipun terjadi. Oleh sebab itu, interaksi akan berlangsung bila ada hubungan timbal balik antara dua orang atau lebih. Interaksi merupakan hubungan yang saling mempengaruhi antara individu dengan individu lain, individu dengan kelompok, dan kelompok dengan kelompok lain. Dengan kata lain secara lebih rinci bahwa interaksi adalah proses individu satu dapat menyesuaikan diri kepada individu yang lain, dimana individu tersebut dipengaruhi oleh individu yang lain. Begitupun sebaliknya Individu yang satu dapat juga menyesuaikan diri dengan individu lain, dimana individu yang lain itulah yang dipengaruhi oleh individu yang pertama. Berdasarkan beberapa uraian di atas dapat diambil kesimpulan bahwa interaksi adalah hubungan timbal balik yang saling mempengaruhi, mengubah, atau memperbaiki perilaku yang berlangsung antara individu dengan individu, individu dengan kelompok, atau kelompok dengan kelompok. Dengan demikian manusia sebagai makhluk individu yang hidup dalam kehidupan masyarakat erat hubungannya dengan interaksi, sehingga manusia disebut makhluk sosial. Keberadaan manusia sebagai makhluk sosial merupakan tidak dapat hidup

\footnotetext{
${ }^{1}$ Onong Uchajana, Dinamika Komunikasi (Bandung, PT Remaja Rosda Karya: 1993) hal 3

${ }^{2}$ Deddy mulyana dkk, Komunikasi Antar Pribadi (Bandung, PT Remaja Rosda Karya:1990) hal 15

${ }^{3}$ Abu Ahmadi, Sosiologi Pendidikan, (Surabaya : Bina Ilmu, 1982), Cet IV, h 42.
} 
dalam kesendirian, ia dapat bertahan dengan manusia lainnya dalam melestarikan interaksi tersebut.

Tampaknya tak dapat dipungkiri lagi bahwa proses interaksi ini sangat vital dan mendasar bagi interaksi sosial, dikatakan vital karena setiap individu memiliki kemampuan untuk berinteraksi dengan individu yang lainnya, dengan begitu menetapkan kredibilitasnya sebagai seorang anggota masyarakat dan dikatakan mendasar karena manusia baik yang primitif maupun yang modern berkeinginan mempertahankan suatu persetujuan mengenai berbagai hal aturan sosial interaksi. Oleh karena itu yang harus ditekankan adalah bagaimana interaksi dapat berjalan efektif dan efisien sehingga pesan yang diterima, ditafsirkan sama antara komunikator dan komunikan. Artinya interaksi yang baik dan efektif, terjadi tidak hanya sekedar saat seseorang telah melekatkan arti tertentu terhadap perilaku orang lain tetapi juga pada persepsinya yang sesuai dengan pemberi pesan atau informasi. Dimana proses interaksi ini menjadi hal yang substantif yang menunjang keberlangsungan hidup bermasyarakat. Disamping itu, proses interaksi juga bisa dijadikan bahan acuan untuk menggali faktor-faktor apa saja yang melatarbelakangi sehingga membentuk pola interaksi yang baik dalam tataran internal komunitas, yang berdampak ketika anggota komunitas tersebut berinteraksi dengan masyarakat. Dengan begitu, kita nantinya akan mengetahui bagaimana pola interaksi yang dibuat oleh komunitas tersebut dalam rangka membenahi sikap para anggotanya sehingga tidak berperilaku menyimpang di masyarakat.

Merupakan hal yang mustahil jika dalam suatu kelompok masyarakat proses interaksinya selalu berjalan harmonis. Pasti keharmonisan itu bersifat fluktuatif. Kadang terjadi konflik, dan terkadang rukun kembali. Namun, yang musti digarisbawahi adalah bagaimana managemen konflik itu bisa dilakukan sehingga tidak terjadi konflik yang berkepanjangan. Untuk itu model interaksi sosial yang dibutuhkan dalam hal ini adalah model yang mengutamakan hubungan individu dengan masyarakat atau orang lain, dan memusatkan perhatiannya kepada proses dimana realita yang ada dipandang sebagai suatu negosiasi sosial. Model ini menekankan pada hubungan personal dan sosial kemasyarakatan diantara individu yang berfokus pada peningkatan pengertian dan pemahaman diri individu untuk berhubungan dengan orang lain, terlibat dalam proses-proses yang demokratis dan bekerja sama secara produktif dalam masyarakat. Terlebih model interaksi sosial ini didasari oleh asas kekeluargaan yang menitikberatkan pada hubungan yang harmonis antara individu dengan masyarakat, maka terjadinya komplik yang ditakutkan dapat dihindari dari sedini mungkin dengan memperbaiki model berinteraksi para individu yang satu dengan individu 
yang lain di tengah-tengah masyarakat. Karena Interaksi dalam hal ini adalah yang sangat urgen dalam kehidupan manusia di dunia ini. Dapat dibayangkan bahwa bila tidak atau tanpa adanya interaksi, manusia akan mengalami kesukaran dalam melestarikan dan mempertahankan hidupnya. Seseorang bisa dikatakan berinteraksi jika dirinya berkomunikasi dengan individu yang lainnya.

Salah satu cara untuk menjamin hal itu juga adalah dengan menghindarkan pesan yang tidak jelas atau tidak spesifik serta dengan meningkatkan frekuensi umpan balik (feedback) guna mengurangi tingkat ketidakpastian dan tanda tanya, yakni dengan cara memahami bagaimana pola interaksi dari lawan tatap muka kita nantinya, sehingga salah tafsir dari penyampaian pesan dapat dihindarkan meskipun mempunyai latar belakang kehidupan yang hampir sama dengan kita. Jika dihubungkan dengan pola interaksi adalah model dari hubungan antar individu dengan individu atau individu dengan kelompok atau kelompok dengan individu dengan memberikan timbal balik antara pihak satu dengan yang lain dengan maksud atau hal-hal tertentu guna mencapai tujuan. Dari interaksi ini akan menghasilkan produk-produk interaksi, yaitu tata pergaulan yang berupa nilai dan norma yang berupa kebaikan dan keburukan dalam ukuran kelompok atau komunitas tersebut. Pandangan tentang apa yang dianggap baik dan apa yang dianggap buruk tersebut mempengaruhi perilaku komunitas sehari-hari. Seperti cara kita berbicara dan berpakaian, makanan yang kita makan dan cara kita menyiapkannya dan mengkonsumsinya, cara kita membagi waktu dan ruang, nilai-nilai yang kita sosialisasikan kepada anak-anak kita dan semua secara rinci lainnya yang membentuk kehidupan sehari-hari.

Perspektif tentang pola interaksi ini mengimplikasikan bahwa tak ada interaksi yang secara inheren lebih unggul dari interaksi yang lainnya dan bahwa pola interaksi tidak ada kaitannya sama sekali dengan status ekonomi, interaksi sebagai kehidupan sehari-hari merupakan idea yang tetap demokratis. ${ }^{.}$Dalam hal ini komunitas Mbojo dalam berinteraksi sangat dipengaruhi oleh tradisi mereka yang sangat khas, mulai dari logat bahasa, cara mereka bertutur kata, menyampaikan pesan yang ada dalam pikiran mereka sampai pada pengungkapan atau pengekspresian perasaan mereka. Komunitas Mbojo mempunyai hubungan yang lebih erat dan mendalam antar sesama warga Mbojonya. Sistem kehidupan biasanya berkelompok, atas dasar kekeluargaan. Dengan prinsip kekeluargaan ini setiap bertanya para pendatang baru, pasti menyebut orang Mbojo pribumi adalah keluarganya, dan uniknya komunitas Mbojo menyepakati hal tersebut.

${ }^{4}$ James Lull, Media, Komunikasi dan Kebudayaan (Jakarta, Yayasan Obor Indonesia :1998) hal. 77 
Pada umumnya komunitas Mbojo dalam pengungkapan perasaan dan pola pikir mereka akan suatu hal cenderung tidak pakai basa basi, langsung pada pembicaraan utama, hal ini dikarenakan masyarakat Mbojo lebih menghargai waktu daripada kemasan pesan yang akan disampaikan. Namun berbeda dengan komunitas Mbojo yang ada di Desa Peresak. Yang lebih menghargai lawan bicara mereka sehingga mereka berusaha semaksimal mungkin memperhalus kemasan pesan mereka agar tidak sampai menyinggung perasaan lawan bicaranya. Meskipun mereka tidak perlu merangkai kata-kata yang indah, tapi enak di dengar, mereka lebih mengutamakan inti pesan, agar pesan tersebut bisa dengan mudah dipahami oleh lawan bicaranya. Kadang kala komunitas Mbojo terlihat sangat emosional dengan nada bicara yang agak tegas, meskipun pesan yang disampaikan mempunyai makna atau arti yang biasa (tidak marah), dan itu merupakan kebiasaan masyarakat Mbojo pada umumnya namun tidak dengan komunitas Mbojo di Peresak. Dalam berinteraksi dengan sesama maupun dengan orang di luar komunitas Mbojo mereka tetap meggunakan bahasa yang halus walaupun kebiasaan bicara dengan nada tinggi masih tetap saja melekat yang sudah menjadi ciri khas orang Mbojo sehingga orang yang diajak bicara harus paham makna pesan yang disampaikan agar tidak terjadi kesalahpahaman yang dapat menyebabkan proses atau menimbulkan konflik dan dalam masyarakat setempat hingga menjadi dasar perilaku anarkis dan tindakan kekerasan yang dilakukan oleh warga yang miskomunikasi kepada pihak yang ada dalam komunitas setempat yang berujung pada tindakan yang tidak diharapkan yang berbau sara dan akibatnya menjadi lebih fatal dalam membangun masyarakat madani yang dicita-citakan semua sebagai masyarakat Indonesia dalam mempertahankan NKRI yang harga mati.

Hal inilah yang memotivasi peneliti untuk mengkaji bagaimana Pola interaksi komunitas Mbojo dengan masyarakat Sasak khususnya di Desa Peresak Kecamatan Narmada Kabupaten Lombok Barat dalam berinteraksi dengan masyarakat pribumi yang terkesan Sopan, Ramah, Lemah lembut bahkan sebagian besar dari mereka mampu berbahasa Sasak krama yang mungkin belum tentu orang Sasak lakukan, hal inilah yang menarik perhatian peneliti untuk mengkaji hal ini.

Dari latar belakang masalah tersebut di atas, maka penelitian ini merumuskan permasalahan sebagai berikut :1. Bagaimanakah pola interaksi komunitas Mbojo dengan masyarakat Sasak di Desa Peresak Kecamatan Narmada Kabupaten Lombok Barat? 2. Bagaimanakah proses interaksi komunitas Mbojo dengan masyarakat Sasak di Desa Peresak Kecamatan Narmada Kabupaten Lombok Barat? 
Bertitik tolak pada rumusan masalah di atas, maka tujuan penelitian ini adalah sebagai berikut : 1.) Untuk mengetahui pola interaksi komunitas Mbojo dengan masyarakat Sasak di Desa Peresak Kecamatan Narmada Kabupaten Lombok Barat. 2.) Untuk mengetahui proses interaksi komunitas Mbojo dengan masyarakat Sasak di Desa Peresak Kecamatan Narmada Kabupaten Lombok Barat.

Adapun kegunaan dari penelitian ini diharapkan berdaya guna yaitu secara teoritis Hasil Penelitian ini; 1). Diharapkan dapat memberikan sumbangan terhadap pengembangan masyarakat terutama tentang pola interaksi masyarakat, 2. Diharapkan dapat memperkaya kajian tentang komunitas masyarakat khususnya di bidang pengembangan Masyarakat Mbojo dan Sasak. Dan secara praktis; 1. Hasil Penelitian ini diharapkan dapat dijadikan salah satu informasi dalam mengembangkan ilmu pengetahuan khususnya kajian yang ada hubungannya dengan Pengembangan masyarakat, 2. Untuk membantu masyarakat demi menghindari kesalahpahaman persepsi dari sebuah interaksi yang disampaikan yang berbeda latar belakang komunitas dalam masyarakat.

\section{Metode Penelitian}

Desain penelitian ini menggunakan penelitian kualitatif. Pada intinya penelitian kualitatif adalah penelitian yang dilakukan pada kondisi objek yang alamiah. Disini peneliti menggunakan instrument kunci. ${ }^{5}$ Pada penelitian ini, peneliti menyajikan hasil penelitian secara kualitatif yaitu data yang dikumpulkan berupa kata-kata, gambar, dan bukan angka. Data tersebut mungkin berasal dari naskah wawancara, catatan lapangan, foto, video, dokumen pribadi, arsip, dan dokumen resmi lainnya. ${ }^{6}$ Peneliti berusaha untuk mendeskripsikan mengenai pola interaksi komunitas mbojo dengan masyarakat sasak di Desa Peresak dengan menggunakan pendekatan kualitatif diharapkan peneliti dapat menggali lebih dalam mengenai tema penelitian ini.

Penelitian ini, menggunakan jenis deskriptif dan fenomenologi. Alfred Schutz sebagai salah satu tokoh teori fenomenologi ini berpendirian bahwa tindakan manusia menjadi suatu hubungan sosial bila manusia memberi arti atau makna tertentu terhadap tindakannya itu, dan manusia lain memahami pula tindakannya itu sebagai sesuatu yang penuh arti. ${ }^{7}$ Sedangkan jenis deskriptif pada hakekatnya adalah mencari teori, bukan menguji teori.

${ }^{5}$ I Made Wirartha. 2006. Metodologi Penelitian Sosial Ekonomi. Yogyakarta :Andi Offset.hal 134 Karya.hal 11

${ }^{6}$ Moleong Lexy J. 2005. Metodologi Penelitian Kualitatif Edisi Revisi. Bandung :Remaja Persada

${ }^{7}$ George Ritzer, Sosiologi Ilmu Pengetahuan Berparadigma Ganda (Yogyakarta: Kanisius, 1992), h. 
Metode ini menitik beratkan pada observasi dan suasana alamiah. Peneliti bertindak sebagai pengamat. Ia hanya membuat kategori pelaku, mengamati gejala dan mencatatnya dalam buku observasi. Dengan suasana alamiah berarti peneliti terjun ke lapangan. Ia tidak berusaha memanipulasi variabel karena kehadirannya mungkin mempengaruhi gejala, peneliti harus berusaha memperkecil pengaruh tersebut. ${ }^{8}$

Lokasi penelitian yang dijadikan obyek atau sasaran dalam penelitian ini. Sebagaimana dijelaskan dalam konseptualisasi penelitian yaitu Pola Interaksi Komunitas Mbojo dengan Masyarakat Sasak studi di Desa Peresak Kecamatan Narmada Kabupaten Lombok Barat, Alasan dipilihnya desa ini adalah karena komunitasnya masih kuat mempertahankan identitas kulturalnya melalui berbagai ritualitas, meskipun mereka tidak tinggal di Bimaa. Kuatnya identitas kultural tersebut diperkuat dengan masih mentradisinya bentuk - bentuk folklor dalam realitas kehidupan sehari - hari.

Dalam penelitian ini, pengumpulan data akan dilakukan langsung oleh peneliti dalam situasi yang sesungguhnya. Teknik pengumpulan data dalam penelitian ini yang digunakan adalah data dokumentasi, wawancara mendalam yang berhubungan dengan data yang diperlukan dan observasi.

Penggunaan data dokumentasi dalam penelitian ini adalah untuk mendapatkan informasi yang berhubungan dengan data-data tentang berbagai hal yang berhubungan dengan pola interaksi sosial komunitas mbojo dengan masyarakat sasak di Desa Peresak Kecamatan Narmada Kabupaten Lombok Barat Seperti peta wilayah, foto-foto dokumenter aktivitas masyarakat mbojo khususnya di Desa Peresak. Teknik dokumentasi ini juga digunakan untuk mendapatkan informasi dan data-data sekunder yang berhubungan dengan fokus penelitian.

Metode wawancara atau disebut juga dengan interview merupakan komunikasi yang dilakukan oleh peneliti untuk mendapatkan informasi dari informan melalui tanya jawab sehingga dapat dikonstruksikan makna dalam suatu topik tertentu. ${ }^{9}$ Interview dalam suatu penelitian yang bertujuan mengumpulkan keterangan tentang kehidupan manusia dalam suatu masyarakat serta pendirian-pendirian masyarakat tersebut, adalah pembantu utama dari metode observasi. ${ }^{10}$ Adapun dalam melakukan wawancara ini peneliti menerapkan langkah-langkah sebagai berikut :

a. Menyusun rambu-rambu pertanyaan yang digunakan dalam wawancara

${ }^{8}$ M. Iqbal Hasan, Pokok-Pokok Materi Metodologi Penelitian dan Aplikasinya, h. 22

${ }^{9}$ Sugiyono. 2009. Metode Penelitian Kuantitatif Kualitatif dan R\&D. Bandung : Alfabeta. Hal 72.

${ }^{10}$ Koentjaraningrat. 1981. Metode-metode penelitian masyarakat. Jakarta: PT Gramedia. Hal 162. 
b. Menetapkan serta menghubungi tokoh-tokoh yang akan diwawancarai

c. Pengaturan waktu dan tempat wawancara

d. Pelaksanaan wawancara setelah diadakan perjanjian dengan tokoh yang dimaksud

e. Pengolahan hasil wawancara

Dalam penelitian ini, jenis wawancara yang dilakukan adalah teknik purposive sampling yakni dengan pertimbangan narasumber yang sudah dianggap paling tahu tentang apa yang diharapkan peneliti atau menguasai sehingga memudahkan peneliti menjelajahi obyek yang diteliti. Dengan adanya penambahan informasi dari masyarakat tentang orangorang yang bisa dijadikan narasumber, maka peneliti juga menggunakan snowball sampling. ${ }^{I I}$ Kemudian penulis juga memilih jenis wawancara semistruktur, yang mana peneliti menggunakan pertanyaan bebas agar informan mengutarakan pandangan dan pengetahuannya mengenai proses interaksi tersebut kepada para tokoh masyarakat maupun masyarakat di kalangan biasa, dengan harapan untuk dapat membandingkan antara hasil observasi langsung dengan hasil wawancara. Beberapa narasumber seperti para tokoh masyarakat yang khusunya terkait dengan pola interaksi komunitas mbojo dengan masyarakat sasak (Studi Pada Komunitas Mbojo di Desa Peresak Kecamatan Narmada Kabupaten Lombok Barat), yang diajukan seluas-luasnya kepada para responden, yang menjadi sasaran peneliti dalam wawancara ini, antara lain :
a. Komunitas Mbojo
b. Tokoh-tokoh masyarakat dan sesepuh adat
c. Dan beberapa masyarakat sekitarnya.

Adapun dalam pelaksanaan wawancara ini penelitian juga menggunakan teknik wawancara bebas terpimpin artinya berbentuk pertanyaan yang diajukan kepada responden bersifat terbuka dan terarah. Teknik ini merupakan kombinasi atau gabungan dari teknik wawancara terpimpin dengan wawancara tidak terpimpin.

Penulis juga mencari sumber lisan yaitu melakukan wawancara langsung dengan tokoh-tokoh atau orang yang mendalangi langsung dan tidak langsung dan orang yang disekitarnya. Menurut Koentjaraningrat, teknik ini bertujuan untuk mengumpulkan informasi yang berupa tanggapan pribadi, pendapat atau opini serta keyakinan. Metode ini dilakukan dengan suatu tujuan khusus untuk mencari keterangan atau pendapat secara lisan dari seorang responden dengan bercakap-cakap dan berhadapan muka mengenai apa yang dilakoni dirasakan, dipikirkan dan diakui.

\footnotetext{
${ }^{11}$ Sugiyono. Op. cit. Hal 73.
} 
Metode ini menggunakan pengamatan atau penginderaan langsung terhadap suatu benda, kondisi, situasi, proses atau perilaku. Pengumpulan data dengan menggunakan alat indera dan diikuti dengan pencatatan secara sistematis terhadap gejala-gejala/fenomena yang diteliti. Metode observasi atau pengamatan meliputi kegiatan pemusatan perhatian terhadap sesuatu obyek dengan menggunakan seluruh alat indera. Metode ini merupakan metode pengumpulan data yang dilakukan secara langsung pada obyek yang menjadi fokus penelitian. ${ }^{12}$ Berangkat dari pengamatan ini, data selanjutnya akan dilaporkan sesuai dengan apa yang dilihat dan didengar tanpa menambah ataupun menguranginya. Kemudian laporan itu akan diwujudkan dalam bentuk deskripsi sesuai apa adanya.

Metode analisis data adalah rangkaian kegiatan penelaahan, pengelompokan, sistematisasi, penafsiran, dan verifikasi data agar sebuah fenomena memiliki nilai sosial, akademik dan ilmiah. Analisis dalam penelitian ini terdiri dari tiga alur kegiatan yang terjadi secara bersamaan. Tahap analisis data dalam penelitian kualitatif secara umum di mulai sejak pengumpulan data 1) reduksi data, yang diartikan sebagai proses pemilihan, pemusatan perhatian pada penyederhanaan, pengabstrakan dan transformasi data kasar yang muncul dari catatan - catatan tertulis di lapangan; 2) penyajian data (display data) dilakukan dengan menggunakan bentuk teks naratif dan 3) penarikan kesimpulan serta verifikasi. ${ }^{13}$

\section{Hasil dan Pembahasan}

Selama melakukan penelitian, baik selama observasi maupun wawancara mengenai Pola Interaksi Komunitas Mbojo dengan masyarakat Sasak di Desa Peresak Kecamatan Narmada Kabupaten Lombok Barat berdasarkan temuan-temuan yang pokok di dalam penelitian, peneliti selanjutnya akan memaparkan yang disesuaikan dengan teori yang mendasarinya antara lain sebagai berikut :

A. Pola Interaksi Komunitas Mbojo dengan masyarakat Sasak di Desa Peresak Kecamatan Narmada Kabupaten Lombok Barat.

Komunitas Mbojo di Desa Peresak dalam berinteraksi mereka menganut dan bersandar pada maja la bo dahu. Hal ini dapat dilihat ketika mereka berinteraksi, baik itu antarindividu, antarkelompok dan antarindividu dengan kelompok.

1. Antar Individu

\footnotetext{
12 Suharsimi Arikunto. 1993. Prosedur penelitian:suatu pendekatan praktik. Yogyakarta: Penerbit Rineka Cipta. Hal 229

${ }^{13}$ Imam Suprayogo dan Tobroni, Metodologi Penelitian Sosial-Agama, h. 192
} 
Komunitas Mbojo yang masih memegang teguh adat-istiadat senantiasa menanam perilaku toleransi dan tepo selero terhadap sesama masyarakat. Dalam berinteraksi di masyarakat, mereka menjadikan lingkungan sebagai alat utama pembentuk sikap toleransi. Walaupun ada beberapa pandangan yang menganggap bahwa sikap itu sudah di bawah sejak lahir, tetapi masih membutuhkan lingkungan sebagai tempat sosialisasi dalam mengembangkan sikap toleransi tersebut. Komunitas Mbojo sebagai masyarakat yang menjunjung tinggi sikap toleransi dan merupakan suatu norma dalam hubungan antar individu (masyarakat) membuat perilaku toleransi tidak asing bagi masyarakat Sasak. H. Mustamin selaku warga masyarakat Mbojo mengatakan bahwa: "masyarakat adat Mbojo sangat menjunjung tinggi perilaku toleransi dan tepo selero, hal ini dibuktikan ketika ada seseorang warga yang bertemu dan atau berpapasan di jalan atau di lingkungan sekitar, maka komunitas Mbojo dengan masyarakat Sasak, mereka dengan ramah dan penuh sopan santun menegur sapa. Sama halnya dalam bertemu saat solat berjamaah di Mushola ataupun di masjid, komunitas Mbojo selalu bersalaman dengan di ikuti senyuman dan diiringi percakapan yang hangat di kedua belah pihak. Oleh karena itu mereka selalu toleransi dan tepo selero dalam bergaul atau berkomunikasi dengan siapa saja. Komunitas Mbojo juga lebih banyak berinteraksi dengan sesama orang Mbojo, dalam hal itulah yang mengakibatkan masyarakat Mbojo mengalami hambatan saat berinteraksi sosial dengan partisipan yang berbeda etnik/suku. Proses komunikasi sesama masyarakat Mbojo terdengar khas dan kurang mengalami hambatan sebab masyarakat Mbojo menggunakan bahasa yang sama yaitu (bahasa Mbojo).

\section{Antarkelompok}

Di dalam masyarakat, beberapa orang berkumpul pastilah proses komunikasi akan berjalan yaitu berinteraksi antarkelompoknya. Suatu komunitas atau kelompok dalam subbagian ini memiliki peran dan fungsinya ketika ada orang yang akan berjumpa tentang sesuatu hal maka interaksi tidak bisa dielakan lagi, misalnya dalam menyelesaikan adat perkawinan, selain itu juga komunitas tersebut dapat mengusulkan beberapa tata aturan dalam berinteraksi terlebih di desa yang tentunya duduk bersama dengan tokoh agama dan aparatur pemerintah seperti Kadus dan Kepala Desa sudah dipastikan sebelumnya.

Sebenarnya pola interaksi yang dilakukan oleh beberapa orang haruslah memperhatikan etika dan norma dalam suatu komunitas dan masyarakat tempat tinggalnya. Para tokoh komunitas hendaknya juga memperhatikan hal-hal yang riskan/beresiko dalam berinteraksi dengan siapapun juga, karena dalam suatu lingkungan yaitu dipimpin oleh 
seorang pemimpin itu memiliki fungsi yang hampir sama dengan tokoh adat lainnya yang mengatur tentang awik-awik dalam bergaul/berinteraksi. Pola interaksi dalam suatu kelompok ini bisa dicontohkan pada pengemban adat yaitu dalam hal ini tokoh komunitas Mbojo. Dalam berinteraksi akan terjadi proses yang sesuai dengan aturan kelompok yang disepakatinya dengan para anggota yang terlibat dalam suatu perkumpul.

3. Antarindividu dengan kelompok

Komunitas Mbojo yang masih kental akan adat-istiadat yang mengikat komunitasnya secara turun temurun dalam kehidupan sehari-hari. Ibrahim, adalah salah satu warga komunitas Mbojo yang sudah sepuh dan dituakan oleh komunitasnya bagi warga Mbojo yang sangat dihormati dan dipatuhi oleh masyarakat Mbojo. Rasa hormat dan penghargaan terhadap tokohnya, sangat terlihat dalam kehidupan sehari-hari komunitas Mbojo. Bukan hanya orang dewasa yang sangat menghormati tokohnya, tetapi para anak kecil juga mengetahui bagaimana seharusnya bersikap kepada sesepuhnya komunitas Mbojo tersebut.

Dalam berinteraksi komunitas Mbojo di Desa Peresak tetap memegang prinsip hidup dari leluhurnya maja la bo dahu (malu dengan takut). Para orang tua di komunitas Mbojo hidup maja bermula dari seorang pemukanya, pemukanya inilah yang memberikan panutan atau yang dicontohi di komunitas dan hidup dengan maja la bo dahu. Maja la bo dahu tersebutlah yang menjadi pedoman dan perilaku hidup komunitas Mbojo yang juga di dalamnya mengajarkan bahwa masyarakat harus lebih bersahaja dari pada pemimpinnya. Hal tersebut didukung oleh pernyataan Bapak Usman mengatakan bahwa: "kalau interaksi terjadi (percakapan/dialog) di jalan, maka orang yang pertama menegur sapa adalah tokohnya. sebaliknya, jika interaksi terjadi di suatu pertemuan, maka para masyarakat komunitas Mbojo yang harus lebih dahulu dipersilahkan untuk mengutarakan pemikirannya, tokohnya kemudian belakangan. Sikap kepemimpinan yang dicontohkan oleh komunitas Mbojo di Desa Peresak tentunya berbanding terbalik dengan sikap pemimpin masyarakat pada umumnya”.

B. Proses interaksi Komunitas Mbojo dengan masyarakat Sasak di Desa Peresak

Kecamatan Narmada Kabupaten Lombok Barat

Proses interaksi komunitas Mbojo merupakan segala bentuk aktifitas atau kegiatan yang dilakukan oleh komunitas Mbojo di Desa Peresak Kecamatan Narmada Kabupaten Lombok Barat. Setiap hari berinteraksi komunitas Mbojo menggunakan bahasa Mbojo sebagai bahasa sehari-hari yang berkembang dalam suatu komunitas masyarakatnya. Menggunakan bahasa Indonesia dalam berkomunikasi membuat mereka lebih nyaman saat 
berkomunikasi dan kecil kemungkinan tidak terjadi kesalahpahaman saat berkomunikasi dengan masyarakat sasak. Sedangkan ketika komunitas Mbojo menggunakan bahasa Mbojo mereka mengalami kesulitan memaknai kata dan merasa tidak nyaman di saat berkomunikasi dengan masyarakat Sasak. Dalam menjalankan kehidupan sehari-hari, masyarakat adat Mbojo memegang teguh ajaran leluhur yang disebut ”maja la bo dahu” yang berarti malu dengan takut. Namun, pesan yang dimaksud bukanlah sembarang pesan, "maja la bo dahu” adalah keseluruhan pengetahuan dan pengalaman tentang segala aspek dan likaliku yang berkaitan dengan kehidupan yang dipesankan secara lisan oleh nenek moyang kepada seluruh masyarakat adat Mbojo. Ajaran tersebut wajib ditaati, dipatuhi, dan dilaksanakan oleh komunitas Mbojo. Proses kehidupan keseharian komunitas Mbojo terbagi menjadi tiga kategori, yaitu segi pekerjaan, segi kekeluargaan dan segi adat-istiadat.

\section{Segi Pekerjaan}

Sebagian besar komunitas Mbojo mempunyai beragam pekerjaan. Mata pencaharian komunitas Mbojo seperti yang diceritakan ibu Ratna (55 tahun) selaku warga komunitas Mbojo mengatakan bahwa: "sebagian besar warga Mbojo setahu saya dik banyak pekerjaannya, ada yang kerja di sawah tanam padi, ada juga yang kerja sebagai guru. Ada juga selain menjadi ibu rumah tangga bekerja sebagai pedagang. Ada juga yang kerja ternak hewan seperti ayam, sapi, kerbau dan ada yang kerja di pasar buruh.” Dari data wawancara diatas dengan ibu Ratna, beliau menyebutkan bahwa rata-rata komunitas Mbojo mempunyai bermacam-macam profesi. Lebih lanjut ibu Ratna menjelaskan bahwa komunitas Mbojo ada yang bekerja di sektor pertanian seperti menanam padi dan jagung. Sedangkan di sektor peternakan ada masyarakat yang bekerja beternak sapi dan ayam. Ada juga ibu rumah tangga yang berprofesi sebagai pedagang. Sedangkan sebagian lainnya menurut ibu Ratna ada yang berprofesi sebagai buruh di pasar. Selama meneliti, peneliti juga mewawancarai orang yang berprofesi sebagai petani yang bernama Musa, berikut petikan wawancara dengan bapak Musa: "saya bekerja sebagai petani. biasanya setiap pagi kalo musim tanam padi. Pergi ke sawahku untuk tanam padi dan membajak sawah. Kalo tanam padi biasanya kerja saling membantu sama warga yang lain. Biasanya saya kerja dari pagi sampe siang. Selain itu kerjaku juga tanam cabe dan palawija. Cuma ituji pekerjaanku untuk saya hidupi keluargaku”.

Berdasarkan wawancara diatas dengan bapak Usman. Beliau menuturkan bahwa setiap hari dia bekerja sebagai petani. Setiap pagi selama musim tanam padi dia menanam padi dibantu 
oleh masyarakat sekitar dari pagi hingga siang hari. Lebih lanjut bapak Usman menjelaskan bahwa selain bekerja menanam padi dia juga bekerja di kebun menanam palawija.

\section{Segi Kekeluargaan}

Komunitas Mbojo benar-benar memupuk rasa kekeluargaan dan saling memuliakan, komunitas Mbojo juga diajarkan untuk bertindak tegas, sabar dan tawakal, karna mereka betul-betul memegang teguh agama dalam berperinsip hidupnya menyimpan pesan-pesan leluhur, yakni komunitas di Desa Peresak harus senantiasa ingat kepada Tuhan. Dalam keluarga masyarakat adat Mbojo mengajarkan untuk taat pada aturan dan melaksanakan semua aturan itu sebaik-baiknya. Sesuai dengan pernyataan informan yang bernama Siti Sarah (59 tahun), berikut petikan wawancaranya: "sebagai masyarakat Mbojo tidak hanya diwajibkan patuh terhadap ajaran agama, tetapi sesama masyarakat kami juga harus saling menghormati dan toleransi satu sama lain, kaum laki-laki wajib patuh terhadap kaum perempuan terutama kepada Ibu. Salah satu contoh adalah apabila didalam perjalanan berpapasan maka kita saling menegur yang terutama lebih dewasa menyapa adik-adiknya untuk memberi contoh sekaligus. Begitu juga dalam menegur sapa lain jenis yaitu kaum perempuan dan kaum pria harus dengan penuh etika dalam bertegur sapa yang jangan sampai ada yang tersinggung atau terlebih tersakiti hatinya. Sesuai dengan pernyataan informan diatas menyatakan bahwa dalam segi kekeluargaan mereka sangat saling menghormati satu sama lain, mereka menjunjung tinggi kemulian dan saling toleransi.

\section{Segi Adat-Istiadat}

Komunitas Mbojo di Desa Peresak mengartikan adat-istiadat sebagai sesuatu yang telah menjadi kebiasaan terus menerus yang berlaku dalam masyarakat dan menjadi kebiasaan masyarakat pada umumnya. Dalam kehidupan sehari-hari masyarakat adat Mbojo mempraktekkan cara hidup yang sangat tahu tata krama yang merupakan salah satu prinsip hidup yang terkandung dalam "maja la bo dahu” yang artinya malu dengan takut. Prinsip hidup maja la bo dahu berarti tahu diri dalam pergaulan tidak ceplas ceplos dalam pergaulan dan berinteraksi dalam kehidupan sehari-hari, baik kepada orangtua maupun dalam hubungan bermasyarakat luar. Komunitas Mbojo berinteraksi juga dalam segala sesuatu yang berbau teknologi seperti HP dan lainnya harus memenuhi prinsip maja la bo dahu, bagi mereka benda-benda teknologi dapat membawa dampak positif dan negatif bagi kehidupan mereka. H.Aref (59 Tahun). 


\section{Simpulan dan Implikasi}

Berdasarkan penelitian yang penulis lakukan dengan menganalisa data, keterangan dan penjelasan yang penulis peroleh maka dapat diperoleh kesimpulan bahwa: 1). Pola Interaksi komunitas Mbojo dengan masyarakat Sasak di Desa Peresak Kecamatan Narmada Kabupaten Lombok Barat adalah memegang prinsip hidup dari leluhurnya yaitu memberi contoh yang terbaik dengan bilhal dari yang lebih tua para tokoh komunitas Mbojo yang sekaligus menjadi panutan dan perilaku hidup komunitas Mbojo yang juga di dalamnya mengajarkan bahwa masyarakat harus lebih bersahaja dari pada pemimpinnya dalam berinteraksi. 2). Proses interaksi komunitas Mbojo dengan masyarakat Sasak di Desa Peresak Kecamatan Narmada Kabupaten Lombok Barat merupakan segala bentuk aktifitas atau kegiatan yang dilakukan setiap hari yang memegang teguh ajaran leluhur yang disebut "maja la bo dahu” yang berarti malu dengan takut dan tercermin dalam tiga kategori, yaitu segi pekerjaan, segi kekeluargaan dan segi adat-istiadat yang merupakan keseluruhan pengetahuan dan pengalaman tentang segala aspek dan lika-liku yang berkaitan dengan kehidupan yang dipesankan secara lisan oleh nenek moyang kepada seluruh masyarakat adat Mbojo.

Berdasarkan pada kesimpulan di atas, terdapat beberapa implikasi teoritis yaitu sebagai berikut: 1). Dengan melihat pola interaksi komunitas Mbojo ini merupakan salah satu cara dalam menyikapai maraknya pergaulan yang tanpa batas dan kendali yang dalam hal ini membentuk atau menjadi trend gaya hidup dalam pergaulan hidup. 2). Penulis berharap agar penelitian ini dapat memberi pemahaman bahwa dalam berinteraksi hendaknya mempunyai prinsip hidup yang kemudian tidak ceplas ceplos dalam pergaulan atau berinteraksi dalam kehidupan sehari-hari, baik kepada orangtua maupun dalam hubungan bermasyarakat luar.

Dari hasil penelitian yang sudah dilaksanakan, telah ditemukan beberapa hal yang dapat menjadi diskusi serta implikasi teoritis yang telah disebutkan, namun agar dapat terealisasikan dengan baik dengan rekomendasi yang dapat menjadi masukan bagi pihak yang berkaitan, dalam hal ini Komunitas Mbojo dan Masyarakat Sasak di Desa Peresak Kecamatan Narmada Kabupaten Lombok Barat adalah supaya dalam pergaulan (berinteraksi) antarkomunitas dan masyarakat harus saling memahami dan pengertian yang lebih mendalam terutama mengenai lingkup pola interaksi dalam suatu komunitas dan masyarakat. 


\section{Daftar Pustaka}

Abu Ahmadi, Sosiologi Pendidikan, (Surabaya : Bina Ilmu, 1982), Cet IV.

Deddy mulyana dkk, 1990, Komunikasi Antar Pribadi (Bandung, PT Remaja Rosda Karya).

George Ritzer, 1992,Sosiologi Ilmu Pengetahuan Berparadigma Ganda (Yogyakarta: Kanisius).

Imam Suprayogo dan Tobroni, 2001, Metodologi Penelitian Sosial-Agama (Bandung: Remaja Rosdakarya)

I Made Wirartha. 2006. Metodologi Penelitian Sosial Ekonomi. Yogyakarta :Andi Offset.

James Lull, 1998, Media, Komunikasi dan Kebudayaan (Jakarta, Yayasan Obor Indonesia)

Koencoroningrat, 1981, Metode-Metode Penelitian Masyarakat, (Jakarta : Gramedia Pustaka Utama,)

Moleong Lexy J. 2005. Metodologi Penelitian Kualitatif Edisi Revisi. Bandung :Remaja Persada Karya.

M. Iqbal Hasan, 2002, Pokok-pokok Materi Metodologi Penelitian dan Aplikasinya, Cet. 1 (Jakarta: Ghalia Indonesia,)

Onong Uchajana, 1993. Dinamika Komunikasi (Bandung, PT Remaja Rosda Karya:)

Sugiyono. 2009. Metode Penelitian Kuantitatif Kualitatif dan R\&D. Bandung : Alfabeta.

Suharsimi Arikunto. 1993. Prosedur penelitian:suatu pendekatan praktik. Yogyakarta: Penerbit Rineka Cipta

Turner dan West, 2008. Pengantar Teori Komunikasi, edisi 3, (Jakarta: Salemba Humanika) 